\title{
AN ARTIFICIAL INTELLIGENCE AND KNOWLEDGE-BASED SYSTEM TO SUPPORT THE DECISION- MAKING PROCESS IN SALES
}

\author{
I.C. Baierle ${ }^{1 *}$, M.A. Sellitto ${ }^{1}$, R. Frozza ${ }^{2}$, J.L. Schaefer ${ }^{2} \&$ A.F. Habekost ${ }^{1}$
}

\section{ARTICLE INFO}

\section{Article details}

Submitted by authors $\quad 4$ Apr 2018

Accepted for publication 3 Jul 2019

Available online $\quad 30$ Aug 2019

Contact details

* Corresponding author

ismacristof84@edu.unisinos.br

Author affiliations

1 Production and Systems

Engineering Department,

University of Vale do Rio dos

Sinos, Brazil

2 Department of Systems and Industrial Process, University of Santa Cruz do Sul, Brazil

DOI

http://dx.doi.org/10.7166/30-2-1964

\section{ABSTRACT}

The purpose of this article is to describe the development of a knowledge-based system that, aided by rules, can support the decision-making processes of the sales department of a company. The knowledge-based system can bring reliability and agility to the decision-making process, and can allow for simulating future scenarios for the company, according to the combined behaviour of key variables. All variables identified in the study have some degree of importance for the decision-making process; they must be analysed together to produce a reliable answer, otherwise, an incorrect decision can emerge, damaging the execution of the company's strategy. The main contribution of this study is a case report in which a knowledge-based system helped to find an adequate alternative to a business problem in the sales sector of a company in the south of Brazil.

\section{OPSOMMING}

Die doel van hierdie artikel is om die ontwikkeling van 'n kennisgebaseerde stelsel te beskryf wat met die hulp van reëls, die besluitnemingsprosesse van die verkope- en bemarkingsafdeling van 'n maatskappy kan ondersteun. Die kennisgebaseerde stelsel kan betroubaarheid en behendigheid tot die besluitnemingsproses bring, en kan toekomstige scenario's vir die maatskappy simuleer, volgens die gekombineerde gedrag van die sleutelveranderlikes. Alle veranderlikes wat in die studie geïdentifiseer is, het ' $n$ mate van belang vir die besluitnemingsproses, en moet saam ontleed word om 'n betroubare antwoord te lewer. Andersins kan 'n verkeerde besluit ontstaan en skade aan die uitvoering van die maatskappy se strategie veroorsaak. Die hoof bydrae van hierdie studie is ' $n$ gevalle studie van ' $n$ geval waarin 'n kennisgebaseerde stelsel gehelp het om 'n voldoende alternatief vir 'n besigheidsprobleem in die verkope-afdeling van 'n maatskappy in die suide van Brasilië te vind.

Today it is not enough for companies only to have greater productivity than their competitors, or to meet the demand for survival and growth in the market. Companies must also have some degree of flexibility to react quickly to competitive market changes, since competitors are often able to copy any new market position quickly. As soon as a competitive advantage is perceived by the market, competitors initiate copying and retaliation [1, 2]. Therefore competitive advantages should be considered by the company as temporary situations.

In the context of these situations, companies that correctly evaluate their internal and external scenarios, creating a flow of intermittent managerial information and transforming information into actions [3], will increasingly stand out in a competitive world. This serves as a basis for all decisionmaking, and thus brings competitiveness to the company. Decision-making based only on previous empirical experiments, without analysing the patterns and information of the current state of the 
environment, can damage an organisation. The learning, storage, and sharing of information and knowledge, with the help of technology, are the attributes considered most effective to improve the performance of companies [4]. Knowledge-based systems can be useful in supporting the decision-making process in the complex environments that characterise contemporary firms [25].

Every decision involves risk; but this risk can be minimised if tools are available that can transform often incomplete data into useful information that can aid decision-making [26]. A simplified process can facilitate the decision-making process at an operational level, making the decision successful, proactive, preventive, and less complex [28]. Data are codes that constitute the raw material of the information - that is, data are the untreated information that still does not have relevance. The data represent one or more meanings of a system that alone cannot transmit a message or represent some knowledge [26]. Knowledge is the interpretation of information in a context - the result of perception, learning, and reason [14]. Figure 1 represents the chain of knowledge management, in which the goals and objectives are drawn by the decision-maker, the data collection, and the analysis (data processing to obtain information) and transformation of information into knowledge (assigning meaning to information). From this, the knowledge will be processed by the rule base and applied in a context/domain to aid decision-making processes in order to achieve satisfactory results in the company's business. These systems, through the rules, are able to achieve good results very rapidly [15].

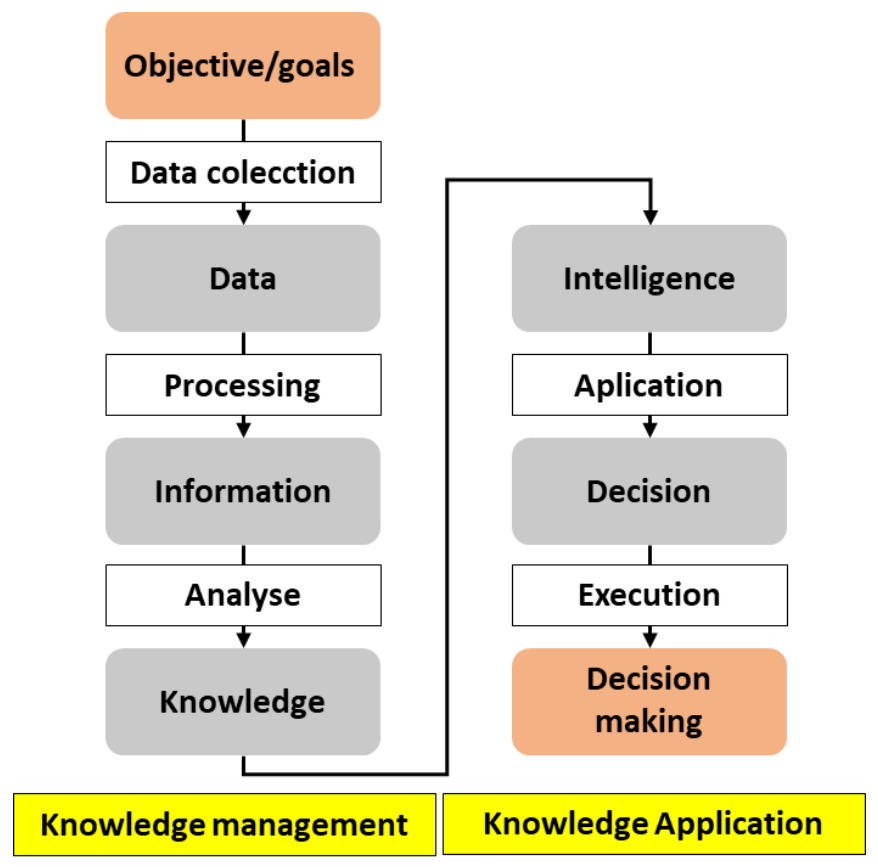

Figure 1: Knowledge management chain

Knowledge-based intelligent systems contribute to an improved business decision-making process, since managers have difficulty organising all available data manually, as becomes evident when they are needed for decision-making [5,6]. Intelligent systems have the ability efficiently to store and retrieve large amounts of data that will be needed to solve problems or make decisions [27]. Due to their autonomous and rational abilities, in addition to streamlining the company's workflow, intelligent systems also ensure the automation and standardisation of business processes, thus optimising them [7].

The basis used to create rules is tacit knowledge - that is, the skills, practical knowledge, or ability to perform work [8] that is the specific knowledge of each manager. Explicit knowledge is already known to all. Considering more than one criterion (and even its sub-criteria) during decision-making makes the decision uncertain [24]. Therefore, what is sought with knowledge-based systems is the transformation of knowledge from tacit to explicit. This must be an advantage, since explicit knowledge is already used and known by all, and can be copied by competitors. However, as tacit 
knowledge is new - that is, knowledge acquired and hitherto retained by the decision-makers of the company - the company can retain its competitive advantage for some time [9].

A knowledge-based system was developed through a single case study in a consumer goods manufacturing company in the south of Brazil. The company has several types of data, but the problem is how to analyse these variables at the same time so that the result can help the decisionmaking processes of the sales department, which is responsible for the sale of the products manufactured by the company. With this case study, we can show that these systems can be used by any company, and that qualitative or quantitative data can be obtained from several sources, all of which make a contribution to decision-making.

\section{KNOWLEDGE-BASED SYSTEMS}

The importance of data and their analysis is growing very rapidly as organisations adapt to leverage their competitive advantage through their information assets [10].

Knowledge-based systems are expert systems that model information and transform it into knowledge. They are used to solve specific problems in specific domains, analysing various types and quantities of data. Their main benefit to organisations is to increase their competitive advantage [11]. Expert systems are intelligent strategies that collaborate with the decision-making of human specialists [12]. In general, they are composed of knowledge about the field of expertise of the specialist [13].

The information can have several sources: a didactic source, publications, or group knowledge. The didactic sources are acquired through direct contact between the provider and the recipient of the information. The published knowledge source is represented by documents, books, catalogues, and postings in the virtual network. Group knowledge refers to the exchange of ideas between two or more people who are able to access and obtain knowledge from a public or closed group [16].

Information from the knowledge-management chain, through the rules, generates the knowledgebased system, which will be able to assist in the proper treatment, distribution, and storage of all of the company's relevant information. This serves as a kind of database for future consultations, and will be very important when required for strategic decision-making.

Knowledge management and knowledge-based systems help companies make wiser decisions, and thus help companies to perform [17]. These systems are based on an explicit model of problemsolving knowledge, replicating the knowledge of the human expert, and are used to solve particular problems in specific domains. They can be used by companies, organisations, and governments to plan ahead and make better, data-driven decisions while maintaining flexibility and agility [18].

An expert system has a knowledge base formed of facts, rules, and heuristics about the domain, as a human expert would develop their activities, and should be able to offer users suggestions and acquire new knowledge and heuristics with this interaction, since the acquisition of knowledge is the main activity in the management of knowledge-based systems [19]. The basic structure for a specialist system consists of three fundamental elements: knowledge base, inference engine, and user interface.

The knowledge base is not a simple collection of information, since the integration of information is very important [21]. The traditional database, archives, and historical records are replaced by a set of rules, facts, and heuristics that correspond to the knowledge of the expert on whom the system was built. The consistency of the rules requires the knowledge of the decision-maker so that it does not generate contradictions [22].

To demonstrate the importance of these systems, we created Table 1 to demonstrate the difference between decision-making based only on a manager's experiences and decision-making through a knowledge-based system.

As seen in Table 1, the use of knowledge-based systems has many advantages, whereas decisionmaking based only on previous experience has many disadvantages. 
Table 1: Advantages and disadvantages of the knowledge-based system

\begin{tabular}{|c|c|c|}
\hline Decision-making & Advantages & Disadvantages \\
\hline $\begin{array}{l}\text { Based only on past experience } \\
\text { or knowledge of manager }\end{array}$ & Accept any kind of decision & 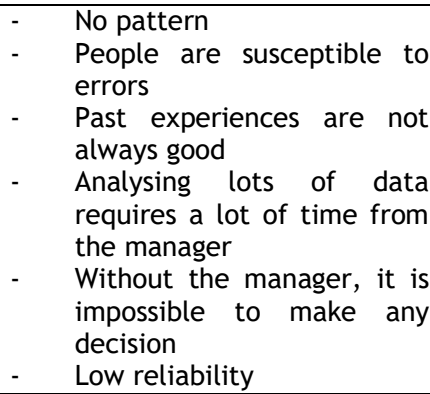 \\
\hline $\begin{array}{l}\text { Based on the analysis of the } \\
\text { variables through the } \\
\text { knowledge-based system }\end{array}$ & $\begin{array}{ll}\text { - } & \text { Pattern in responses } \\
\text { - } & \text { Analysis of a large amount of } \\
\text { data in a short time } \\
\text { - }\end{array}$ & $\begin{array}{l}\text { Does not accept decisions that } \\
\text { are different from the rules }\end{array}$ \\
\hline
\end{tabular}

\section{THE RESEARCH}

The research object was a consumer goods manufacturing company in the south of Brazil whose main product is raincoats for motorcyclists. The work method can be detailed as follows: (i) collecting data through a search of historical data available in the company's sales department, and a search on Brazilian Institute of Geography and Statistics (IBGE) websites, Abraciclo (Brazilian Association of Manufacturers of Motorcycles, Mopeds, Scooters, Bicycles and Similar), and the Center for Weather Forecasting and Climate Studies (CPTEC); (ii) classifying data through unstructured surveys conducted in meetings with company directors, taking their tacit knowledge into account; (iii) structuring the database and defining the variables involved in the decision-making process; (iv) creating the set of rules, with the aid of the intelligent system; and (v) finalising and presenting the system, showing its applicability in the company.

The choice for this data was made because it is public and periodically updated - that is, decisionmaking takes actual data into account, never estimated data. This increases the reliability of the results and directs the company towards better decision-making.

The data collected constitute the inputs to the knowledge-based system, and are also the factors that influence the strategic actions of the company, focusing mainly on the best positioning and greater competitiveness in the market. From the meetings, we selected data that would make it possible to draw a profile of consumers, the market situation, and a climate assessment of a given region. These are all determining factors for the company segment - i.e., the data influence the company's strategic actions, as can be seen in Figure 2.

The collected data is analysed from a set of rules that are pre-established by the company's decisionmakers. This set of rules causes the system to perform the analysis of all data intelligently, giving the decision-maker an indication of the best strategy to be adopted. Support for the decision-making process is the output of the expert system. This output should help to make the correct decision with the current knowledge; and by observing reality, new knowledge must be produced [23], thus forming a cycle, as indicated in Figure 2. 


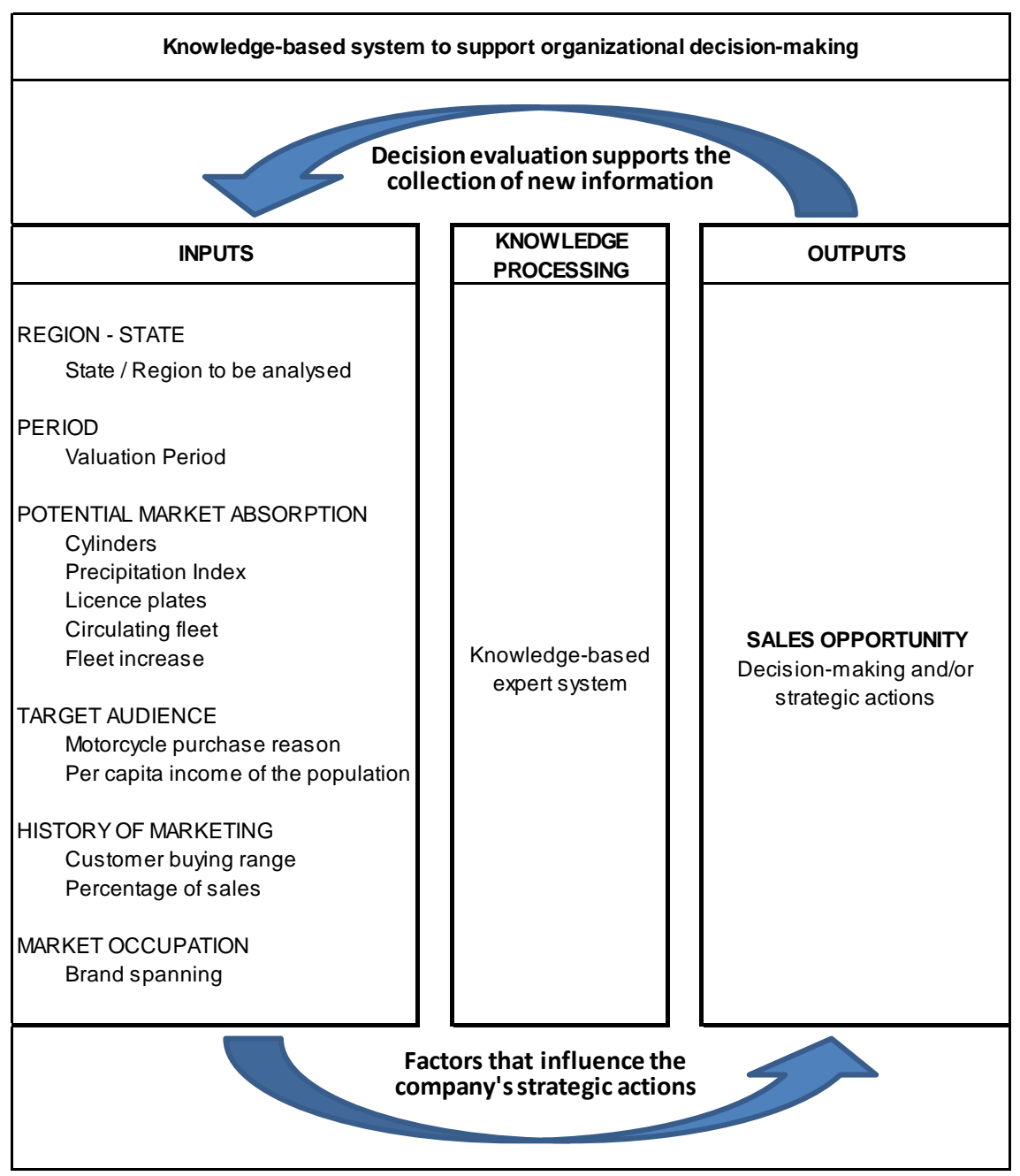

Figure 2: Specialist system attributes flowchart

The collected data are properly separated by Brazilian states and by period (usually monthly) before being inserted into the system. Because it is a seasonal product, the sales vary greatly according to the month and the Brazilian state. Table 2 shows the entire process of knowledge generation by the expert system, with the questions asked and the response options. After answering all the questions, the expert system, through the rules developed, analyses the answers to generate the output: four objective variables that are processed again by the system, through new rules, to reach the end result, which is the support for decision-making.

For the development, storage, and execution of the rules, the free software based on knowledge SINTA 1995-1997, version 1.1b, created by the SINTA Group (Applied Intelligent Systems) of the Laboratory of Artificial Intelligence of the Federal University of Ceará (UFC), was used. All steps, from data entry to knowledge process termination, are performed by a set of rules (Table 3 ) that are stored in the database of the expert system. All input data is entered by the user in the expert system, through pre-set questions and with standardised response options, except for those involving monetary values or percentages.

The four objective variables, which refer to the response that will be provided by the expert system and that directly influence the product sales, market prospects, and brand work, are: (i) market absorption potential; (ii) target audience; (iii) sales history; and (iv) market share. All of these variables are classified according to the responses entered by the user and, after being inserted through the set of rules, the system performs a first analysis of the data and generates a single result for each of the four variables. From the beginning to the end, the system has a total of 144 rules, consisting of the simulation of the most different scenarios and of the most different situations [21]. 
Table 2: Knowledge generation process through the system

\begin{tabular}{|c|c|c|}
\hline Question of the expert system & $\begin{array}{l}\text { Answer (according to the } \\
\text { data collected) }\end{array}$ & Objective variables \\
\hline $\begin{array}{l}\text { What is the dominant engine capacity in the } \\
\text { state? }\end{array}$ & $\begin{array}{c}\text { Up to } 100 \\
\text { from } 101 \text { to } 150 \\
\text { from } 151 \text { to } 250 \\
\text { above } 251\end{array}$ & \multirow{4}{*}{$\begin{array}{l}\text { MARKET ABSORPTION } \\
\text { POTENTIAL }\end{array}$} \\
\hline $\begin{array}{c}\text { What is the state's average precipitation index } \\
\text { for the period? }\end{array}$ & 0 to $1000 \mathrm{~mm}$ & \\
\hline $\begin{array}{l}\text { How many new motorcycles were registered in } \\
\text { the period? }\end{array}$ & 0 to $100 \%$ & \\
\hline $\begin{array}{l}\text { What is the percentage of the motorcycle fleet } \\
\text { in the state in the period? }\end{array}$ & 0 to $100 \%$ & \\
\hline $\begin{array}{l}\text { What is the dominant reason for purchasing } \\
\text { motorcycles in the state? }\end{array}$ & $\begin{array}{c}\text { Replace old motorcycle } \\
\text { Replace public transport } \\
\text { Investment } \\
\text { Recreation } \\
\text { Replace Car } \\
\text { Lowest value } \\
\text { Quality } \\
\text { Another motive }\end{array}$ & \multirow[t]{2}{*}{ TARGET PUBLIC } \\
\hline $\begin{array}{l}\text { What is the income range of the state } \\
\text { population? }\end{array}$ & $\mathrm{R} \$ 0$ to $10,000.00$ & \\
\hline $\begin{array}{c}\text { What is the average range of customer } \\
\text { purchases in the period? }\end{array}$ & $\begin{array}{l}\text { Low } \\
\text { Medium } \\
\text { High }\end{array}$ & \multirow{2}{*}{ HISTORICAL SALES } \\
\hline $\begin{array}{l}\text { What is the sales history for the period in the } \\
\text { state? }\end{array}$ & $\begin{array}{l}\text { Low } \\
\text { Medium } \\
\text { High }\end{array}$ & \\
\hline $\begin{array}{l}\text { What is the percentage of coverage of the } \\
\text { brand in the state? }\end{array}$ & 0 to $100 \%$ & MARKET SHARE \\
\hline
\end{tabular}

It is possible to see an example rule for each target variable in Table 3, where each rule is considered to be a different decision that could be made. In summary, there are 144 different ways of interpreting information entered into the system.

Table 3: Example rules

\begin{tabular}{|c|c|}
\hline Variable & Example rules \\
\hline MARKET SHARE & $\begin{array}{l}\text { Rule } 43 \\
\text { IF Brand scope (knowledge) > } 30 \\
\text { THEN MARKET SHARE = Well-known brand }\end{array}$ \\
\hline $\begin{array}{c}\text { MARKET ABSORPTION } \\
\text { POTENTIAL }\end{array}$ & $\begin{array}{l}\text { Rule } 84 \\
\text { IF Market potential = High } \\
\text { AND Rainfall in the state = Rainy } \\
\text { AND Sales by engine capacity = Daily use - Priority is price } \\
\text { THEN POTENTIAL MARKET ABSORPTION = Excellent potential - Invest in low-cost } \\
\text { products }\end{array}$ \\
\hline PUBLIC TARGET & $\begin{array}{l}\text { Rule } 91 \\
\text { IF Income per capita = Low purchasing power } \\
\text { And Motorcycle buying reasons = Daily use - Great potential } \\
\text { THEN PUBLIC TARGET = Low income - Daily use }\end{array}$ \\
\hline HISTORICAL SALES & $\begin{array}{l}\text { Rule } 112 \\
\text { IF Sales history = Low } \\
\text { AND Range of purchases = Average } \\
\text { THEN HISTORICAL SALES = Good buying range - Low sales history }\end{array}$ \\
\hline
\end{tabular}


This first set of rules brings together all the data considered from the same area and transforms them into new values, which, together with other data, will serve as the basis for more advanced rules in the next step. The next step is the evaluation of the four objective variables, made by the system itself. It will do a general analysis of all the results and make the decision about the main output of the system, which is the final variable, 'Sales opportunity'. The value of this variable is generated automatically by the system at the end of the whole process. This is the main information that the decision-maker needs to support the decision.

As discussed in the previous section, the knowledge-based system, from the inference process on the knowledge-base rule set, generates a value for the final variable, 'Sales opportunity'. Table 4 shows the sixteen different types of decision-making that can be generated by the system.

\section{Table 4: Support for decision-making}

\begin{tabular}{|c|c|}
\hline & Possible actions proposed by the system \\
\hline \multirow{16}{*}{ 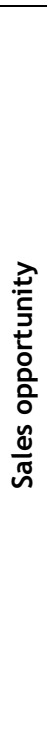 } & Low sales history. Work more on branding with low-cost products. Population has low income. \\
\hline & Analyse potential stores. Low sales history and low-income population. \\
\hline & Low sales history, but population has good income and motorcycles are used daily. \\
\hline & $\begin{array}{l}\text { Average sales potential. Customers with great potential. Population has good income and uses } \\
\text { motorcycles for leisure. You can invest in value-added products. }\end{array}$ \\
\hline & $\begin{array}{l}\text { Great sales potential. Customers with great potential. Population has good income. You can invest in } \\
\text { value-added products. }\end{array}$ \\
\hline & Great sales potential. Customers buy large quantities. Population has low income, seeks lower cost. \\
\hline & $\begin{array}{l}\text { Great sales potential. Customers buy large quantities. Population has good income and uses } \\
\text { motorcycles for leisure. You can invest in value-added products. }\end{array}$ \\
\hline & $\begin{array}{l}\text { Great sales potential. Customers buy large quantities. Population has good income. You can invest in } \\
\text { value-added products. }\end{array}$ \\
\hline & Low sales history, but region has good income, and most use a motorcycle for leisure. \\
\hline & Low sales history. Work more on the brand with higher value-added products. \\
\hline & $\begin{array}{l}\text { Good sales opportunity. Average income range, but use motorcycles eventually. Invest in value-added } \\
\text { products. }\end{array}$ \\
\hline & Average sales opportunity. Low income region. Invest in low-cost products. \\
\hline & Very good sales opportunity. Population has good income and uses motorcycles daily. \\
\hline & $\begin{array}{l}\text { Very good sales opportunity. Population has good income and uses motorcycles daily, but range of } \\
\text { customers buying is low. }\end{array}$ \\
\hline & Population with good income who use motorcycles for leisure. Evaluate points of sale. \\
\hline & Low sales history. Work more on branding with low-cost products. Low-income population. \\
\hline
\end{tabular}

In response, the system will indicate the actual sales opportunity according to the data analysed and processed by the system. It will be the finalisation of the process, and will propose a final action to be evaluated by the human expert. As predicted in the most diverse scenarios, it would not be possible, using a manual method, to be efficient and error-free in generating sixteen different types of proposals for decision-making, always following the same standards.

For the verification and validation of the system, the simulation was done in a specific month of the year when raincoat sales are low and the specialist needs to make a decision in order to improve sales. But to make that decision, the specialist needs to know all the parameters. One parameter is the amount of rain - that is, if it is not raining, it will be difficult to sell raincoats, and it is no use incurring advertising expenses and demanding targets from sellers, because those will be costs that will not be converted into sales, since this product is only remembered when it is needed - that is, when it is raining. This expert system gives the expert an indication of the best decision to take. The developed system has data for about 10 years, with data for periods with more rain, periods with greater sales, the states of Brazil in which raincoats sell more frequently in a given month, and the states of Brazil that have more registered motorcycles and thus represent possible customers. So when you enter data such as the month and the state in Brazil, it will tell the expert whether to take immediate action or to wait for the next month when, historically, sales are more favourable.

Finally, the manager will use the final information generated by the system, which provides her or him with the necessary inputs to assist in decision-making. Because it is the last step, you can also view a report with all the rules (use of variables) generated by the system until the making of the decision, so that the manager can analyse each step leading to the result produced by the expert 
system. As an output in this process, the decision is presented with the purpose of all the data processing, where the information generated should lead to some strategic action. The action must be in accordance with the position of the company in the market, generating new knowledge for the organisation.

The result of the sales opportunity will indicate to the decision-maker what direction should be taken in order for the company to be successful against its competitors and in the face of market adversity.

\section{CONCLUSION}

This research has shown that information is important for decision-making: it is a reference point that guarantees that the manager and/or decision-maker can reach an adequate conclusion about the positioning of the organisation in the market. Artificial intelligence, through knowledge-based systems, offers support that guarantees the organisation the storage of this information, facilitating access to it when necessary and for any purpose - but especially as a basis for new decision-making strategies.

The collected data were organized through a set of rules and used to develop the intelligent knowledge-based system to be used as a basis for decision making. The intelligent system directly influences business decisions by enabling you to predict what scenarios might look like through the set of rules, which were created based on the manager's market experience along with external data.

All stages of the intelligence-building cycle are included in the system, since it encompasses both internal and external data, for further analysis through the created set of rules. The manager evaluates and uses the available information in the decision-making process, planning the next strategic action and a new round of data collection. The expert system, through the set of rules, ensures that no information is disregarded, thus generating a more reliable decision. This will also ensure the standardisation of future actions and decisions.

We live in the knowledge age, and knowledge-based systems transform collected data and individual experiences into information that will be critical for decision-making. Thus technologies for knowledge management are becoming increasingly important.

This shows us that all companies should think about automating their decision-making processes, so that they are not held hostage by the tacit knowledge of only one person or a small number of people. Decision-making, for the most part, decides a company's new directions or new strategies; and, if they are not aligned with market realities and do not always have the same pattern, could lead to great losses for the company.

The importance of this specialist system for business in general is that humans are unable to crosscheck historical data for a 10-year period (for example) quickly, effectively, and in a standardised way. Decisions without standards tend to face a greater risk of there being uncertainties; and this can be detrimental to businesses, causing unnecessary costs and expenses, employee dissatisfaction, production problems, and so on. As the expert system takes historical data into account, new data will always be inserted. This means that the ideal solution today may not be ideal in the future; and so specialised knowledge becomes vulnerable, unlike that of the system.

It is suggested that, for future work, performance indicators within the company should be created so that strategic actions and decision-making can be evaluated. These indicators should be used to evaluate the rules of the system and to improve them - or even to create new ones.

\section{REFERENCES}

[1] Coff, R.W. 2010. The coevolution of rent appropriation and capability development. Strategic Management Journal, 31(7), 711-733.

[2] Marcel, J.J., Barr, P.S. \& Duhaime, I.M. 2011. The influence of executive cognition on competitive dynamics. Strategic Management Journal, 32(2), 115-138.

[3] Lindblom, A. \& Tikkanen, H. 2010. Knowledge creation and business format franchising. Management Decision, 48(2), 179-188. 
[4] Lim, M.K., Tseng, M.L., Tan, K.H. \& Bui, T.D. 2017. Knowledge management in sustainable supply chain management: Improving performance through an interpretive structural modelling approach. Journal of Cleaner Production, 162, 806-816.

[5] De Miguel, L., Bustince, H., Fernández, J., Induráin, E., Kolesárová, A. \& Mesiar, R. 2016. Construction of admissible linear orders for interval-valued Atanassov intuitionistic fuzzy sets with an application to decision making. Information Fusion, 27, 189-197.

[6] Meng, F., Chen, X., Zhu, M. \& Lin, J. 2015. Two new methods for deriving the priority vector from interval multiplicative preference relations. Information Fusion, 26, 122-135.

[7] Ahmed, M., Ahmad, M.S. \& Yusoff, M.Z.M. 2012. A collaborative framework for multiagent systems. International Journal of Agent Technologies and Systems (IJATS), 3(4), 1-18.

[8] Salazar-Fierro, P. \& Bayardo, J.M. 2015. Influence of relational psychological contract and affective commitment in the intentions of employee to share tacit knowledge. Open Journal of Business and Management, 3(03), 300.

[9] do Rosário, C.R., Kipper, L.M., Frozza, R. \& Mariani, B.B. 2015. Modeling of tacit knowledge in industry: Simulations on the variables of industrial processes. Expert Systems with Applications, 42(3), 1613-1625.

[10] Grover, P. \& Kar, A.K. 2017. Big data analytics: A review on theoretical contributions and tools used in literature. Global Journal of Flexible Systems Management, 18(3), 203-229.

[11] Li, J.Q., Rusmevichientong, P., Simester, D., Tsitsiklis, J.N. \& Zoumpoulis, S.I. 2015. The value of field experiments. Management Science, 61(7), 1722-1740.

[12] do Nascimento, R.J.O., Fonseca, C.A.G. \& de Medeiros Neto, F.D. 2017. Using expert systems for investigating the impact of architectural anomalies on software reuse. IEEE Latin America Transactions, 15(2), 374-379.

[13] Luger, G.F. 2004. Inteligência artificial: Estruturas e estratégias para a solução de problemas complexos. Bookman, São Paulo, Brazil.

[14] Shbair, M.W., AlSarraj, W.F. \& Kahloot, K.M. 2016. The impact of factors of success on the in-house software development for preserving tacit knowledge: survey. Arab Journal of Science and Research Publishing, 17(3220), 1-10).

[15] Paiva, F.A.P., Costa, J.A.F. \& Silva, C.R.M. 2017. A serendipity-based approach to enhance particle swarm optimization using scout particles. IEEE Latin America Transactions, 15(6), 1101-1112.

[16] Kim, J., Song, J. \& Jones, D.R. 2011. The cognitive selection framework for knowledge acquisition strategies in virtual communities. International Journal of Information Management, 31(2), 111-120.

[17] Yu, J.B., Yu, Y., Wang, L.N., Yuan, Z. \& Ji, X. 2016. The knowledge modeling system of ready-mixed concrete enterprise and artificial intelligence with ANN-GA for manufacturing production. Journal of Intelligent Manufacturing, 27(4), 905-914.

[18] Sushil. 2017. Multi-criteria valuation of flexibility initiatives using integrated TISM-IRP with a big data framework. Production Planning \& Control, 28(11-12), 999-1010.

[19] Kim, J.S. 2014. Development of a composite knowledge manipulation tool: Kexpert. Expert Systems with Applications, 41, 4337-4348.

[20] Feng, G., Zhang, J.D. \& Liao, S.S. 2014. A novel method for combining Bayesian networks, theoretical analysis, and its applications. Pattern Recognition, 47(5), 2057-2069.

[21] Júnior, O.L., Schnitman, L. \& Lepikson, H. 2004. Uma arquitetura neural hibrida para extração de regras nebulosas. IEEE Latin America Transactions, 2(2), 126-131.

[22] Wan, S., Wang, F. \& Dong, J. 2018. A group decision making method with interval valued fuzzy preference relations based on the geometric consistency. Information Fusion, 40, 87-100.

[23] Petrov, S. 2018. Dynamics properties of knowledge acquisition. Cognitive Systems Research, 47, 12-15.

[24] Yildiz, A. \& Yayla, A.Y. 2015. Multi-criteria decision-making methods for supplier selection: A literature review. South African Journal of Industrial Engineering, 26(2), 158-177.

[25] Weber, C.A., Current, J.D. \& Desai, A. 2000. An optimization approach to determining the number of vendors to employ. Supply Chain Management: An International Journal, 5(2), pp. 90-98.

[26] Taylan, O., Alidrisi, H. \& Kabli, M. 2014. A multi-criteria decision-making approach that combines fuzzy topsis and DEA methodologies. South African Journal of Industrial Engineering, 25(3), 39-56.

[27] Cruz-Domínguez, O. \& Santos-Mayorga, R. 2016. Artificial intelligence applied to assigned merchandise location in retail sales systems. South African Journal of Industrial Engineering, 27(1), 112-124.

[28] Burnett, S. \& Vlok, P.J. 2014. A simplified numerical decision-making methodology for physical asset management decisions. South African Journal of Industrial Engineering, 25(1), 162-175. 